\title{
RURAL INFRASTRUCTURE AND PROFITABILITY OF FOOD CROP PRODUCTION IN OYO STATE, NIGERIA
}

\author{
DAUd, S. A. ${ }^{1}$ - OMOTAYO, A. O. ${ }^{2,3^{*}}-$ AREMU, A. O. ${ }^{2,3^{*}}-$ OMOTOSO, A. B. ${ }^{4}$ \\ ${ }^{1}$ Department of Agricultural Extension and Management, Oyo State College of Agriculture and \\ Technology, Private Mail Bag 10, Igbo-Ora, Oyo State, Nigeria \\ ${ }^{2}$ Indigenous Knowledge Systems (IKS) Centre, Faculty of Natural and Agricultural Sciences, \\ North West University, Private Mail Bag X2046, Mmabatho 2790, North West Province, South \\ Africa \\ ${ }^{3}$ Food Security and Safety Niche Area, Faculty of Natural and Agricultural Sciences, North \\ West University, Private Mail Bag X2046, Mmabatho 2790, North West Province, South Africa \\ ${ }^{4}$ Department of Cooperative Economics and Management, Oyo State College of Agriculture and \\ Technology, Private Mail Bag 10, Igbo-Ora, Oyo State, Nigeria \\ *Corresponding author \\ e-mail: omotayoabiodun777@gmail.com; phone: +27-18-389-2573 \\ (Received 26 $6^{\text {th }}$ Mar 2018; accepted $3^{\text {rd }}$ Jul 2018)
}

\begin{abstract}
The role of infrastructure in promoting development in Nigeria cannot be overemphasized, given its importance in economic wellbeing of the populace and growth of the economy. This study examined the influence of infrastructure on the profitability of food crop production among rural farming households in Oyo State, Nigeria. Data were collected on six infrastructural facilities (tarred roads, potable water, market, health centre, storage facilities and school). Multi-stage sampling technique was used to select 120 farmers from two Agricultural zones of Oyo state. Data were analyzed using Descriptive statistic, Budgeting Analysis (BA) and Ordinary Least Square regression (OLS). OLS was employed to determine factors affecting profitability of food crop production in the study area and the model was well-fitted. Findings revealed that the majority (70.0\%) of the respondents were male with $74.0 \%$ of them married and had a mean farm size of 12 ha. Based on the current state of rural infrastructure, $47.5 \%$ of the respondents reported that available tarred roads are functioning as against $23.0 \%$ of them whom reported that health facilities were not functioning. The study concluded that rural infrastructure is essential to the output of agriculture production in the study area. Rehabilitation of rural roads and the general upgrading of the rural infrastructures which will boost agricultural production across the state is recommended.
\end{abstract}

Keywords: budgeting analysis, descriptive statistics, ordinary least square regression, rural infrastructure, Nigeria

\section{Introduction}

In Nigeria, agriculture involves forestry, livestock, fishing as well as farming of food and cash crops such as yams, cassava, maize, cocoa, groundnut and oil palm. The country is largely endowed with natural resources (e.g. abundant land supply, human and forestry) that are necessary for the development of agriculture. The country has a total land area of about 98.3 million ha out of which 71.2 million ha $(72.4 \%)$ are cultivable but only 34.2 million ha $(34.8 \%)$ are currently in use (Daramola, 2014). In the country, agriculture faces a number of challenges and the majority of the farmers still depend on subsistence agriculture for their livelihood. More than $64 \%$ of people in the rural areas are not able to meet their basic food needs, and well over $50 \%$ of women 
still engage in subsistence agriculture for survival (Ale, 2004). Other challenges include under-developed land property rights, infrastructural inadequacies, limited irrigation and inadequate storage facilities (Ashok and Balasubramanian, 2006).

Rural infrastructural is basic physical and organisation structures needed for the operation of a society or enterprises, or the services and facilities necessary for an economy, infrastructure is a set of investments that include rural roads, water supply, rural housing, rural electrification, sanitation, energy and telecommunication and agricultural processing (Anija-Obi, 2001). These facilities enhance the standard of living of rural famers (Onwuemenyi, 2008). The improvement of rural infrastructure is highly related to agricultural production in various ways. For instance, it is is one of the several subject of activities that are essential for rural transformation. Thus, the existence of poor quality or inadequate infrastructure will inevitably have a negative impact on agriculture (Patel, 2014).

Poor access to infrastructural facilities such as healthcare centre, educational institutions, communication gadgets and water supply lead to low agricultural production. This status and development of rural people enhance the quality of rural labour (Pinstrup-Andersen and Shimokawa, 2006). Agricultural development is essential for economic growth, rural development and poverty alleviation in low income and developing countries. Productivity increase in agriculture is an effective driver of economic growth and poverty reduction both within and outside agricultural sectors (Onwuemenyi, 2008). Such productivity increase depends on rural infrastructures, wellfunctional domestic markets, appropriate institutions and access to appropriate technology. While the state of rural infrastructures varies widely among developing countries, lower income countries including Nigeria suffer severe rural infrastructure deficiencies (Ekong, 2003).

Presently, Nigerian food crop production sub-sector is dominated by weak and inefficient producer-market linkages due to poor infrastructure including lack of improved processing facilities, low farm productivity, poor post-harvest handling and storage, expensive and poor access to inputs (high quality seeds, fertilizing and crop protection products), inadequate market information, lack of transparency among players, low capacity to meet quality standards, and limited efficiency distribution networks. This has declined rice productivity and low income for the rice farmers in Nigeria, especially in Oyo State.

\section{Problem statement}

Agriculture infrastructure although involves huge initial capital investments, long gestation periods, high incremental capital output ratio, high risks and low rates of returns on investments and increasing crop yields, thereby promoting agricultural growth (Patel, 2014). Government initiatives to improve the quality and quantity of infrastructure in the rural areas through programmes such as the construction of small dams and boreholes for rural water supply and the clearing of feeder roads for the evacuation of agricultural produce and the supply of electricity to rural areas from large irrigation Dams, the establishment of nine River Basin Development Authorities (RBDAs) in addition to the two existing ones (Sokoto and Rima RBDAs); DFRRI, the Poverty Relief and Infrastructure Investment Fund and the Comprehensive Agricultural Support Programme, have registered limited impact on the lives of many rural people (World Bank, 2006). The effort by government to increase productivity of farmers has been fulfill thus has adversely affected the level of agricultural production and socio- 
economic life of rural farmers because the improvement of these infrastructure are not available in the area of study. Rural infrastructure such as roads, irrigation, transportation, primary markets and weather forecasting services can reduces production cost, transportation cost, storage expenses, dealing cost and operation risk and enhance efficiently. Deficient infrastructures have negative implication on the present state of agriculture.

Agricultural production is still highly dominated by the small holder farming system. The farms are dominated by small scale farmers who are responsible for about $95 \%$ of total production (Fasoranti, 2004). This is not unconnected with the unattractiveness of agriculture which is a result of lack of necessary infrastructures in the rural areas which forms the bulk of agricultural zones in the country. In addition, small scale agriculture has in the time past suffered from limited access to credit facilities, modern technology farm inputs and inefficient use of resources. Nevertheless, it is on record that $50 \%$ of world's population is dependent on subsistence agriculture. In the words of Akande (2003), food cropping system and the postharvest services in Nigeria encompass a wide range of agricultural activities ranging from land clearing, seed bed preparation, broad casting, fertilizer application, weeding and bird scaring. Others include harvesting, threshing, parboiling, drying, winnowing, bagging and marketing and distribution. These activities are largely executed manually, women and children, the very vulnerable segments of the society are largely involved. Food crop production expansion in Nigeria is therefore bound to reduce drastically the foreign exchange spending on food importation and more importantly it could lead to the transfer to money into hands of the very vulnerable group of the Nigeria economy.

As indicated by Fakayode et al. (2009), the provision of efficient infrastructures is now widely recognize as indispensable to agricultural progress as it is known fact that infrastructure can support economic growth, reduce poverty and make development environmentally sustainable. In any modern society, infrastructure plays a pivotal and often a decisive role in determining the overall productivity and development of a countries economy as well as the quality of life of the citizens. The role of infrastructure such as electricity, transportation networks, safe water, and good health centre in promoting development cannot be overemphasized. The improvement increases the efficiency of production and contributes to standard living (PCU-NFDO, 2005). Rural infrastructure and development have enormous implication on production outcome in agricultural sector and over all significant development of the country. The effort by government to increase productivity of farmers has not been effective, and this has adversely affected the level of agricultural production and socio-economic life of rural farmers because the improvement of these infrastructures is not catered for in the area of study (Fakayode et al., 2009).

Felloni et al. (2001) reported that rural infrastructure such as roads, irrigation, transportation, and primary market and weather forecasting services can decrease production and transportation cost, storage expenses; dealing cost and operation risk and enhance efficiency. Deficient infrastructures have great negative implications on present state of agriculture. The United Nations (2009), estimated that $48.3 \%$ of Nigeria's population live in the urban areas while the majority of the people $(51.7 \%)$ live in the rural areas and they are largely engaged in agricultural production. Agriculture as the traditional mainstay of Nigeria's economy is a prominent industry in the rural areas, and its development is expected to have positive spill-over effects on food security, rural infrastructural development, and overall rural development. Thus, 
the immense values of the rural communities in overall national development have prompted both past and present administrations to formulate series of policies and programmes aimed at transforming rural-Nigeria. In order to ameliorate this solution, it is important to know the available infrastructures in the area so that more recommendations can be made to enhance farming operations. It is against this background that the study will provide the answers to the following questions:

1. What are the existing rural infrastructures in the study area?

2. What is the current state of existing rural infrastructures?

3. How do these rural infrastructures affect agricultural productivity in the study area?

\section{Aim of the study}

This study focused on the effect of rural infrastructure on profitability of food crop production in rural farming households in Oyo state, Nigeria.

The objectives are to

1. Describe the socio-economic characteristics of the respondents

2. Examine current state of the existing rural infrastructure

3. Determine the effect of these infrastructures on farm productivity

4. Estimate the profitability of crop farmers in the study area.

\section{Materials and methods}

\section{Methodology}

The study was conducted in Oyo State which has its capital in Ibadan (Figs. 1 and 2). The study area covers approximately an area of $28,454 \mathrm{~km}^{2}$ with an estimated population of 5,591,589 people (NPC, 2006). It is an inland state in South-Western Nigeria. It bounded in the north by Kwara state, in the east by Osun State and the south by Ogun State. The income generating activities in the area includes: trading, farming, hunting, blacksmithing, weaving, tailoring and carpentry. The major crops cultivated in the area include yam, maize, cassava, okra, melon, groundnut and cash crops such as mango, cashew and citrus.

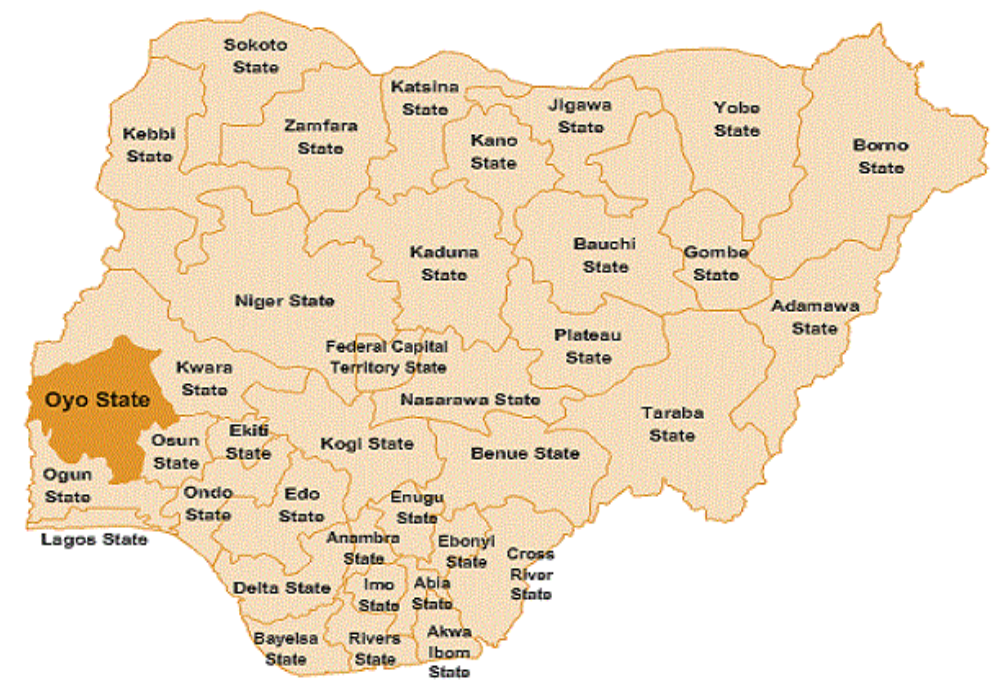

Figure 1. Map of Nigeria with Oyo State highlighted in orange. (Source: Ndianaefo, 2016) 


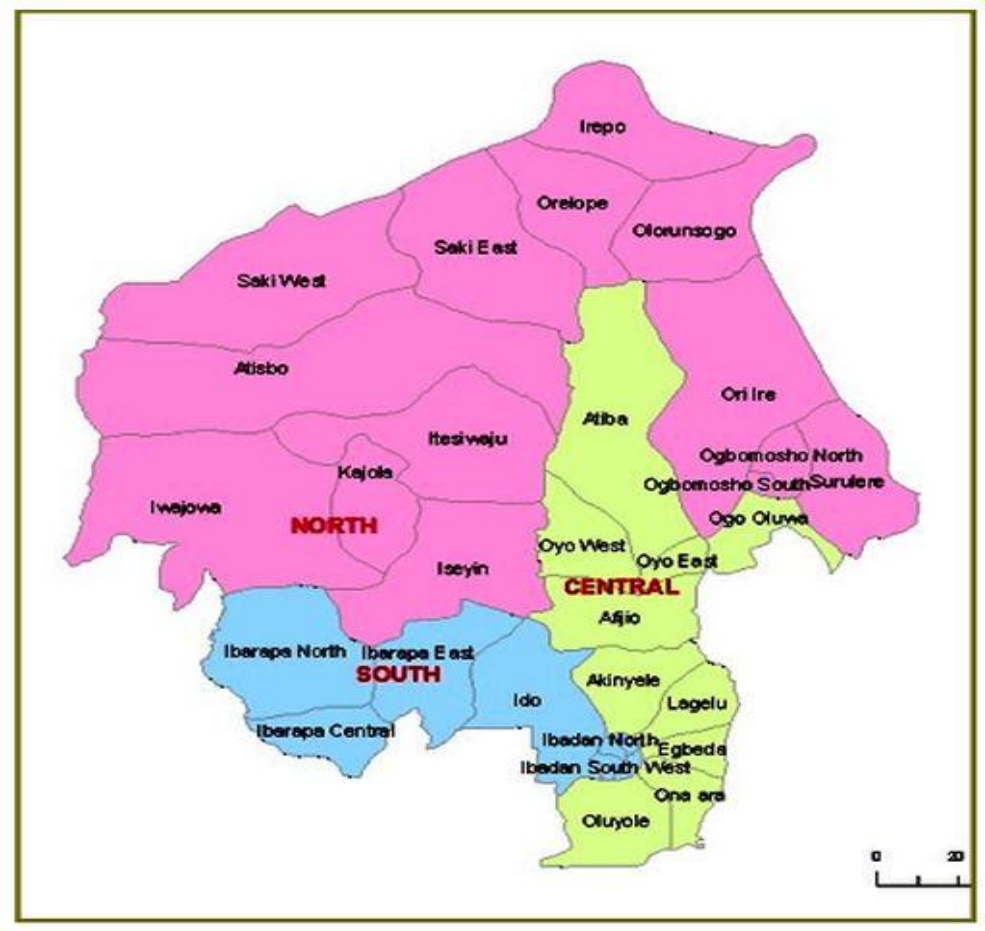

Figure 2. Map of Oyo State indicating the local government areas and Agricultural Development Programme (ADP) Zones. (Source: Nigerian Muse, 2010)

\section{Model specification}

Ordinary least square regression analysis

$$
\begin{gathered}
\operatorname{Ln} y=\beta_{1} \operatorname{In} X_{1}+\beta_{2} \operatorname{In} X_{2}+\ldots \ldots \ldots \beta_{n} \operatorname{InX} X_{n}+e \\
Y=f\left(X_{1}, X_{2}, X_{3}, X_{4}, X_{5} \ldots \ldots \ldots \ldots \ldots \ldots \ldots \ldots \ldots X_{14}, U\right)
\end{gathered}
$$

$\mathrm{Y}=$ Gross margin ( $), \mathrm{X}_{1}=$ Farm size (hectare), $\mathrm{X}_{2}=$ cost of hired labour, $\mathrm{X}_{4}=$ Educational Status, $\mathrm{X}_{5}=$ Farming Experience (Years), $\mathrm{X}_{6}=$ Age of household head (Years), $X_{7}=$ distance to Potable water (if present, yes $=1$, no $=0$ ), $X_{8}=$ distance to Tarred Road (if present, yes $=1$, no $=0$ ), $X_{9}=$ Schools (if present, yes $=1$, no $=0$ ), $\mathrm{X}_{10}=$ Market (if present, yes $=1$, no $=0$ ), $\mathrm{X}_{11}=$ Health Centre (if present, yes $=1$, no $=$ 0 ), $X_{12}=$ Storage Facilities (if present, yes $=1$, no $=0$ ), e $=$ Error term.

\section{Results and discussion}

\section{Demographic characteristics of food crop farmers}

The socio-economic distribution of food crop farmers varied for all the parameters evaluated (Table 1). For instance, $38.0 \%$ of the respondents fall between age group of 20-40 with the mean age of 44 years while about $19.0 \%$ of the respondents are above 61 year old. This finding is similar to that of Fasoranti (2004) who reported on cost and return of crop production in Akure, Ondo State, Nigeria. One could infer from this result that crop farmers in the study area are young, active and still in the productive age. Also, the result of socio-economic distributions of the respondents showed that 
majorities $(70.0 \%)$ of the respondents were male while $30.0 \%$ were female. This implies that male are actively involved in farming. This could be attributed to the fact that Nigerian cultures do not permit women free access to and control over land (Rahji, 2007).

Table 1. Socio-economic characteristics of the respondents. (Source: Field Survey, 2014)

\begin{tabular}{|c|c|c|c|}
\hline Characteristics & Frequency & Percentage & Mean \\
\hline \multicolumn{4}{|l|}{ Age } \\
\hline $20-40$ & 45 & 37.3 & \multirow{4}{*}{44} \\
\hline $41-50$ & 26 & 21.8 & \\
\hline $51-60$ & 27 & 22.5 & \\
\hline 61 and above & 22 & 18.4 & \\
\hline \multicolumn{4}{|l|}{ Gender } \\
\hline Male & 80 & 70.0 & \\
\hline Female & 40 & 30.0 & \\
\hline \multicolumn{4}{|l|}{ Marital status } \\
\hline Single & 0 & 0 & \\
\hline Married & 89 & 74.2 & \\
\hline Widowed & 19 & 15.8 & \\
\hline Divorced & 12 & 10 & \\
\hline \multicolumn{4}{|l|}{ Educational level } \\
\hline No formal & 54 & 45.0 & \\
\hline Primary education & 35 & 29.2 & \\
\hline Secondary education & 26 & 21.7 & \\
\hline Tertiary education & 5 & 4.1 & \\
\hline \multicolumn{4}{|l|}{ Years of farming } \\
\hline Less than 10 & 40 & 33.6 & \multirow{6}{*}{22} \\
\hline $10-20$ & 29 & 24.1 & \\
\hline $21-30$ & 21 & 17.4 & \\
\hline $31-40$ & 10 & 8.3 & \\
\hline $41-50$ & 13 & 10.8 & \\
\hline Above 50 & 7 & 5.8 & \\
\hline \multicolumn{4}{|l|}{ Farm size } \\
\hline Less than 10 & 93 & 77.6 & \multirow{3}{*}{12} \\
\hline $11-20$ & 26 & 21.6 & \\
\hline Above 20 & 1 & 0.8 & \\
\hline \multicolumn{4}{|l|}{ Religion status } \\
\hline Christainity & 67 & 55.4 & \\
\hline Islam & 53 & 44.6 & \\
\hline Traditional & 0 & 0 & \\
\hline \multicolumn{4}{|l|}{ Household size } \\
\hline $1-5$ & 54 & 43.3 & \multirow{3}{*}{6.5} \\
\hline 6-10 & 50 & 41.7 & \\
\hline Above 10 & 18 & 15.0 & \\
\hline \multicolumn{4}{|l|}{ Primary occupation } \\
\hline Artisan & 21 & 18.2 & \\
\hline Civil servant & 2 & 1.6 & \\
\hline Farming & 87 & 72.0 & \\
\hline Trading & 10 & 8.2 & \\
\hline Total & 120 & 100.0 & \\
\hline
\end{tabular}


In terms of formal educational level of food crop farmers, $45.0 \%$ of the respondents has no formal education, those with tertiary education were about $4.0 \%$ and about $22.0 \%$ of the respondents had secondary education. The percentage of uneducated rural farmers is an indication of the level of infrastructure (school) in the study area. This result was in line with Mundluk et al. (2002) who reported that a large proportion of rural households continue to lack access to basic services. Furthermore, the duration of years spent farming indicated that $33.0 \%$ have spent between 1-10 years in farming, $24.1 \%$ of the rural farmers have spent 11-20 years in farming. Anijah-Obi (2001) corroborated this findings that longer year of farming experience helps the farmers to make rational choices and decision.

\section{Perceived state of rural infrastructure in the study area}

The perceived state of the selected rural infrastructure in the study area was evaluated (Table 2). Relative to tarred road, $47.5 \%$ of food crop farmers indicated that the road present are still functioning while about $4.0 \%$ of them reported that the available road are not functioning due bad state of disrepair. Among the respondents, $8.0 \%$ of them of had access to functioning potable water as against $5.0 \%$ that reported that the available market are been abandoned. Furthermore, $22.0 \%$ of the respondents have access to functioning healthcare service in the study area as against about $13.4 \%$ that had no access to storage facilities. According to FAO (2005 rural infrastructure plays a crucial role in poverty reduction, economic growth and empowerment for the Africa poor. Farmers efforts to escape poverty and overcome subsistence agricultural levels are been limited by the present of infrastructure in the study area, poor access to market, poor storage facilities and extension contact.

Table 2. Perceived state of rural infrastructure in the study area. (Source: Field Survey, 2014. Freq $=$ frequency)

\begin{tabular}{c|c|c|c|c|c|c|c|c}
\hline \multirow{2}{*}{ Infrastructure } & \multicolumn{2}{|c|}{ Functional } & \multicolumn{2}{c|}{ Not functional } & \multicolumn{2}{c|}{ Partially functional } & \multicolumn{2}{c}{ Abandoned } \\
\cline { 2 - 8 } & Freq & \% & Freq & \% & Freq & \% & Freq & \% \\
\hline Tarred road & 57 & 47.50 & 5 & 4.20 & 38 & 31.70 & 20 & 16.60 \\
Potable water & 74 & 61.60 & 11 & 9.20 & 25 & 20.80 & 10 & 8.40 \\
Market & 79 & 65.80 & 22 & 18.40 & 13 & 10.80 & 6 & 5.00 \\
School & 17 & 21.20 & 18 & 15.00 & 69 & 57.50 & 16 & 13.30 \\
Health & 25 & 20.80 & 15 & 12.50 & 72 & 60.00 & 8 & 6.70 \\
Storage & 21 & 17.50 & 58 & 48.30 & 25 & 20.80 & 10 & 13.40 \\
\hline
\end{tabular}

\section{Budgeting analysis of food crop farmers in Oyo State}

Gross margin was used to estimate the cost and return on food crop production in the study area as presented thus: $\mathrm{GM}=\mathrm{TR}-\mathrm{TVC}$

$$
\begin{gathered}
\text { Benefit cost ratio }(\mathrm{BCR})=\frac{T R}{T C} \\
\mathrm{TC}=\mathrm{TFC}+\mathrm{TVC}
\end{gathered}
$$


where $\mathrm{TC}=$ total cost, $\mathrm{TR}=$ total revenue, $\mathrm{TC}=$ total cost, $\mathrm{TR}=$ total revenue, $\mathrm{TFC}=$ total fixed cost, $\mathrm{TVC}=$ total variable cost, $\mathrm{GM}=$ gross margin,

$\mathrm{TR}=\$ 233909.5$,

$\mathrm{TVC}=\mathrm{N} 122053.9$,

$\mathrm{TFC}=\mathrm{N9200.0,}$

$\mathrm{TC}=131253.9$,

$\mathrm{GM}=\mathrm{N} 233909.5-\mathrm{N} 131253.9=\mathrm{N} 102655.6$

$$
\mathrm{BCR}=\frac{233909.5}{131253.9}=1.8
$$

Given that the BCR is greater than 1, it shows that the crop production is profitable in the study area. This implies that for every $\$ 1.00$ invested in agriculture in the study area, an expected return of 1.80 is certain with all things been equal.

This conformed with the findings of (Omotayo and Oladejo, 2016; Ekpe and Alimba, 2013) on food crop production in Ebonyi State which has positive gross margin as shown by the study because Total Revenue (TR) is far more than Total Variable cost (TVC). The profitability of crop enterprise and farmers income is expected to increase significantly if more land is put under food crop production.

\section{Regression analysis}

Result of the determinant of profitability of food crop production in the study area was presented in Table 3. The marginal effects of the independent variables were estimated because they are very important for policy and decision making. Parameter estimate of OLS revealed that farm size, potable water, storage facilities and quantity of agrochemicals used are significantly related to the farmers' profitability. Furthermore, total household size, educational level of the respondent, health, market and school are statistically not significant to farmers' production. This may be due to the availability of extension service, their scale of production is low and majority of them used local storage facilities. This is in line with the result of the work done by Okorie et al. (2011), who noted that farmers with increased household size obtained higher yield due to family labour supply. This reduces the cost of production since family labour is not paid for. The educational qualification of rice farmers bore positive signed coefficient and was not statistically significant.

The positive relationship indicates that the higher the level of education of the farmers, the higher their yield in rice production. This is true because educated farmers are intelligent and calculative in utilization of available resources and are able to adopt innovation on rice products. Unlike uneducated farmers who has low adoption level. Furthermore, it also implies that better education and more farming experience in terms of longer years may improve awareness of potential benefits and willingness to participate in local natural resource management and conservation activities. This result was in conformity with Ekong (2003), which explained that the spread of needed infrastructure and introduction of appropriate technology in rural areas would markedly improve rural economy and their output. Adjusted $\mathrm{R}^{2}$ value of 0.507 implies that $50.7 \%$ variability in farmer's profitability is explained by the independent variables while the remaining $49.3 \%$ of the variability is accounted for by the error term and the excluded variables. 
Table 3. Parameter estimate of ordinary least square $(O L S)$ regression

\begin{tabular}{c|c|c|c}
\hline Variable & Coeficient & t-ratio & Significant \\
\hline Constant & 2.267 & 1.897 & 0.061 \\
Household size & 0.008 & 0.211 & 0.221 \\
Educational status & 0.255 & 1.569 & 0.119 \\
Age of household head & 0.008 & 0.516 & 0.607 \\
Farming experience & -0.009 & -0.723 & 0.471 \\
Farm size & 0.082 & $1.834^{* *}$ & 0.049 \\
State of road & -0.106 & -0.472 & 0.638 \\
State of potable water & -0.331 & $1.666^{*}$ & 0.099 \\
State of market facilities & -0.176 & -0.706 & 0.482 \\
State of health facilities & -0.115 & -0.403 & 0.687 \\
State of storage & 0.202 & $1.673^{*}$ & 0.097 \\
State of school & -0.010 & -0.102 & 0.919 \\
Quantity of agrochemicals & 6.230 & $3.092^{* * *}$ & 0.003 \\
\hline
\end{tabular}

* significant at $10 \% ; * *$ significant at $5 \% ; * * *$ significant at $1 \%$

\section{Conclusion and recommendation}

The analysis of the socio-economic characteristics of the respondents showed that majority of the farmers are old and quite experienced in food crop production. Based on the findings from this study, it is evident that male are more involved in farming enterprise than female in the study area. Majority of the respondents are married, under basic education and mean household size of 12 persons. The study further revealed that food crop production is profitable in the study area with BCR of 1.8 which implies that for every 1.00 invested in agriculture in the study area, an expected return of 1.80 is certain with all things been equal. The result of the regression analysis showed that farm size, state of potable water, storage facilities and quantity of agrochemical used were statistically significant and had influence on farmers' profitability in the study area. Therefore, government and Non-government organization (NGOs) should collaborate with farmers with a view in providing the needed infrastructure in order of their priorities so as to increase their production in the study area.

1. Government should provide the rural farmers with necessary agricultural inputs at a subsidized level as this will equally enhances their productivity.

2. On basic healthcare facilities, both Government and Non-governmental Organizations (NGOs) should help in developing the rural health sector so as to increase labour availability and at the long run improve the productivity.

3. This research calls for general rehabilitation of the infrastructural facilities in the study area with a view of encouraging more people to agriculture and improving their productivity.

4. Government should work with existing social organization and involve them in distribution of necessary inputs for rice production.

5. Timely provision of necessary farm inputs to enhance rice production.

Acknowledgements. We appreciate the financial support from the Research Support Office and Faculty of Natural and Agricultural Sciences (FNAS), North West University, Mmabatho as well as the National Research Foundation (NRF), Pretoria, South Africa. 


\section{REFERENCES}

[1] Akande, S. O., Akpokodje, G. (2003): Food Prices and Market Integration in Selected Areas in NIGERIA. Project Report. The Nigerian Rice Economy in Competitive World: Constraints, Opportunities and Strategies Choices. - Institute of Social and Economic Research (NISER), Ibadan, pp. 1-20.

[2] Anija-Obi, F. N. (2001): Fundamental of Environmental Education and Management. University of Calabar Press, Calabar, pp. 230-233.

[3] Ale, M. O. (2004): Achieving food security in Nigeria: A focus on information and communication Technology. - Nigerian Journal of Research and Production 5(2): 141146.

[4] Ashok, K. R., Balasubramanian, R. (2006): Role of Infrastructure in Productivity and Diversification of Agriculture. - South Asia Network of Economic Research Institutes (SANEI). Pakistan Institute of Development Economics, Islamabad, Pakistan, pp. 1-39.

[5] Daramola, A. G. (2014): Competitiveness of Nigeria Agriculture in a Global Economy: Any Dividends of Democracy? - Inaugural Lecture Series 36 delivered at the Federal University of Technology, Akure, 2 March, 2004.

[6] Ekong, E. E. (2003): An Introduction to Rural Sociology. - Jumar Publishers, Ibadan, pp. 68-75.

[7] Ekpe, I. I., Alimba, J. O. (2013): Economics of rice production in Ebonyi State South East Nigeria. - International Journal of Food, Agriculture and Veterinary Sciences 3(2): 77-81.

[8] Fakayode, S. B., Rahji, M. A.Y, Oni, O. A., Adeyemi, M. O. (2009): An assessment of food security situations of farm households in Nigeria: A USDA approach. - The Social Sciences Journal 4(1): 24-29.

[9] Fasoranti, K. O. (2004): Comparative Cost and Return in Maize Production in Nigeria. NISER Individual Research Project Report, NISER, Ibadan, pp: 1-35.

[10] Felloni, F., Wahl, T., Wandschneider, P., Gilbert, J. (2001): Infrastructure and Agriculture Production: Cross-Country Evidence and Implications for China. - USDAWCC, Seattle (USA), pp.103-119.

[11] Food and Agricultural Organisation (FAO) (2005): Comprehensive Africa Agricultural Development Programme. - FAO Corporate Document Repository. www.fao.org. Accessed on 10 November 2006.

[12] Mundlak, Y., Larson, D., Butzer, R. (2002): Determinants of Agricultural Growth in Indonesia, the Philippines, and Thailand. - World Bank Policy Research Working Paper 2803.

[13] National Population Commission (2006): Nigeria Population Census. - NPC, Abuja.

[14] Ndianaefo, M. (2016): Nigeria; agric. Oyo Initiative gets investors' pledges. https://www.cp-africa.com/2016/04/27/nigeria-agricoyo-initiative-gets-investorspledges/. Accessed on 5 July 2018.

[15] Nigerian Muse (2010): Map of various states and their local government in Nigeria. https://www.nigerianmuse.com/20100527092749zg/sections/pictures-maps-

cartoons/maps-of-various-states-and-their-local-governments-in-nigeria/. Accessed on 5 July 2018.

[16] Okorie, K. C., Nkwocha, G. A. Ndubuisi, E. C. (2011): Implications of feeding varying dietary levels of cassava leaf meal on finisher broilers: Performance, carcass haematology and serological profiles. - Global Research Journal of Science 1: 58-66.

[17] Omotayo, A. O., Oladejo, A. J. (2016): Profitability of cassava-based production systems. - Journal of Human Ecology 56(1-2):196-203.

[18] Onwuemenyi, O. (2008): Taking agriculture to commercial status in Nigeria. - Punch Newspaper, Sunday, 21 Sep 2008.

[19] Patel, A. (2014): Infrastructure for agriculture and rural development in India: need for a comprehensive program and adequate investment. 
http://www.microfinancegateway.org/gm/document1.9.47445/Infrastructure\%20For\%20 Agriculture.pdf. Accessed on 7 April 2014.

[20] Pinstrup-Andersen, P., Shimokawa, S. (2006): Rural Infrastructure and Agricultural Development. $\quad-\quad$ World https://books.google.co.za/books?hl=en\&lr=\&id=S0gIIfP4OGUC\&oi=fnd\&pg=PA175\& $\mathrm{dq}=$ Per+Pinstrup+and+Satoru,+2006\&ots=bC0GtirxKc\&sig=aS1tvAITNLXcjeXKTkW_

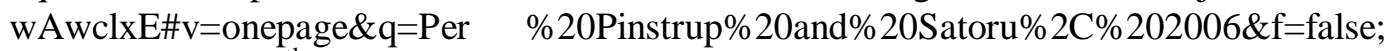
Accessed on the $5^{\text {th }}$ July 2018.

[21] Projects Coordinating Unit - National Fadama Development Office (PCU-NFDO) (2005): Poverty Reduction and Increased Productivity through Empowerment. Fadama Development Project. - National Fadama Development Office. Projects Coordinating Unit. Federal Ministry of Agriculture and Rural Development, Abuja.

[22] Rahji, M. (2007): Rural infrastructure, farm output and productivity nexus in a multi-crop economy, the case of Oyo State, Nigeria. - Proceedings of the 21st Annual National of Farm Management Association of Nigeria 3-6 September 2007, Olabisi Onabanjo University, Yewa Campus, Ayetoro.

[23] United Nations (2009): The State of the World Cities: Trend in Sub-Saharan Africa Urbanisation and Metropolitanisation. - www.unhabitat.org.

[24] United Nations Development Programme and United Nations Development Programme (2007): Fighting Climate Change: Human Solidarity in a Divided World. - Palgrave Macmillan, London, pp. 1-18.

[25] World Bank (2006): World Development Report 2003: Sustainable Development in a Dynamic World: Transforming Institutions, Growth, and Quality of Life. - World Bank and Oxford University Press, New York. 